Letter

\section{I do not want my baby screened for COVID-19}

Consent can be a difficult issue, especially in children's health. We describe two cases where our current pandemic has caused a novel issue in this area.

A child with a complex background presented with croup to their local district general hospital. While there was no suspicion of COVID-19 infection, hospital policy dictated all admissions to the ward should be screened for COVID-19, regardless of presentation. The mother refused consent for the swab as she did not display the classical symptoms. The second patient presented to a tertiary hospital with high temperatures and joint pain and met the hospital criteria for COVID-19 testing. The mother refused consent for the swab, though agreed to isolate with the family for 2 weeks. The child was treated with suspected COVID-19 precautions while an inpatient.

In the first case, the child would not have met criteria for testing due to symptoms alone and only required the test for admission, though the patient was quickly well enough for discharge, and there was no ongoing consequence for nursing care, precautions or bed management. In the second case, despite the child having a temperature and requiring admission, the mother refused consent for the COVID-19 swab as she did not want to distress her son. The fever mandated the child being treated as a possible case of COVID-19, which led to a clear impact on staff caring for the child, bed management as well as the contacts of the patient.
We know, as defined by our legal bodies, we can over-rule parents withholding consent if lack of intervention would result in death or severe permanent disfigurement. Clearly, this is not the case in these instances, though in times of a global pandemic, the arguable moral and social obligations to carry out appropriate screening are not being met. Such obligations are not normally enforceable, but the picture becomes complicated with the existence of UK COVID-19 laws and penalties for failing to comply.

The solution to this situation of consenting for COVID-19 swabs is probably exploring the reasons why consent is withheld. Parents may simply be worried about the procedure, hence time and gentle explanation may be all that is needed. However, while awaiting a result, the child and family may need to isolate and this could result in loss of school time, loss of parental earnings and impact the psychosocial well-being of families. Another influencing factor may be the fear of a positive result, and this may lead to the problems just described.

Both these cases were discussed in an ethics committee meeting. While there is no clear answer, clearly we should not be refusing treatment based on a refusal of screening, especially in children. There is a need for published guidance for these instances, but also clear and transparent criteria, augmented by good communication, for patients and parents to understand the necessity and importance of COVID-19 testing.

Deborah Kelly, ${ }^{1}$ Nehali Dal $\odot,{ }^{2}$ Pradip Thakker ${ }^{2}$

${ }^{1}$ Department of Paediatrics, Nobles Hospital, Braddan, Isle of Man
${ }^{2}$ Department of Paediatrics, Queen's Medical Centre Nottingham University Hospital NHS Trust, Nottingham, UK

Correspondence to Dr Pradip Thakker, Paediatrics, Queen's Medical Centre Nottingham University Hospital NHS Trust, Nottingham, Nottingham, UK; Pradumal.Thakker123@gmail.com

Contributors DK initiated and produced the initial manuscript. ND adapted the letter with support from PT.

Funding The authors have not declared a specific grant for this research from any funding agency in the public, commercial or not-for-profit sectors.

Competing interests None declared.

Patient consent for publication Not required.

Provenance and peer review Not commissioned; internally peer reviewed.

\section{(2) OPEN ACCESS}

Open access This is an open access article distributed in accordance with the Creative Commons Attribution Non Commercial (CC BY-NC 4.0) license, which permits others to distribute, remix, adapt, build upon this work non-commercially, and license their derivative works on different terms, provided the original work is properly cited, appropriate credit is given, any changes made indicated, and the use is non-commercial. See: http:// creativecommons.org/licenses/by-nc/4.0/.

(C) Author(s) (or their employer(s)) 2021. Re-use permitted under CC BY-NC. No commercial re-use. See rights and permissions. Published by BMJ.

$$
\text { A) Check for updates }
$$

To cite Kelly D, Dal N, Thakker P. Arch Dis Child 2021;106:e36.

Accepted 10 February 2021

Published Online First 2 March 2021

Arch Dis Child 2021;106:e36.

doi:10.1136/archdischild-2020-321443

\section{ORCID iD}

Nehali Dal http://orcid.org/0000-0001-9664-3630 